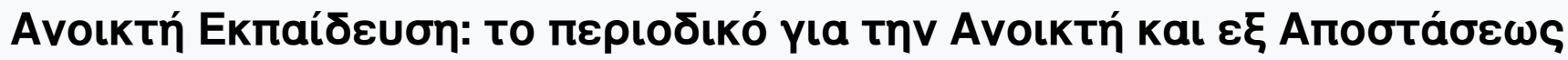

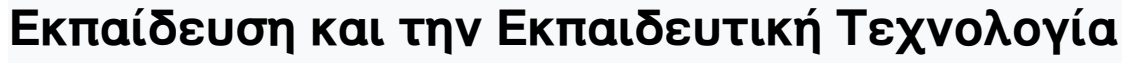

Tóp. 13, Ap. 2 (2017)

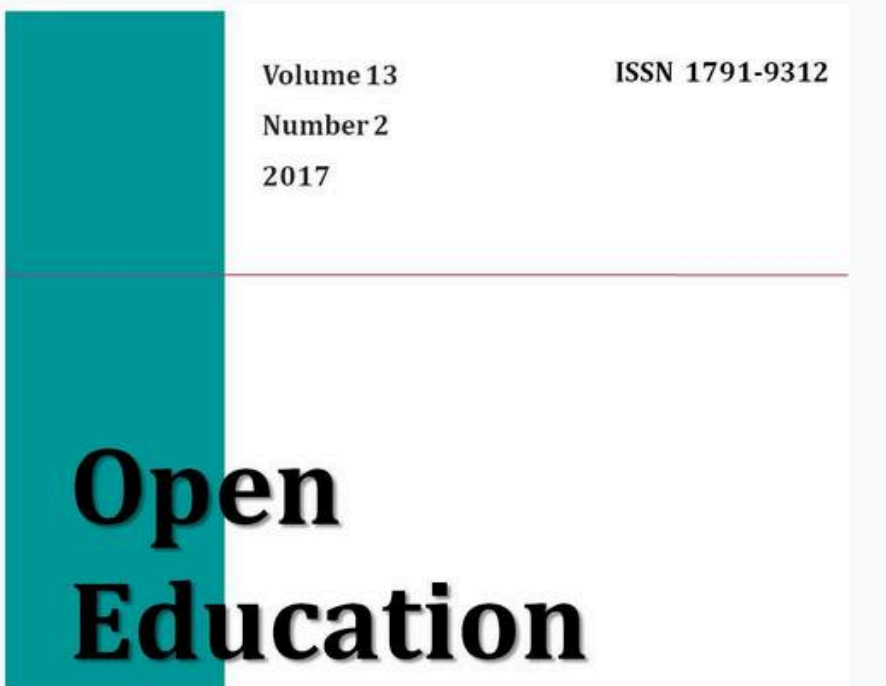

Peer Support during Student Teachers' Practicum: A Case Study using a Web 2.0 Community on the Cloud

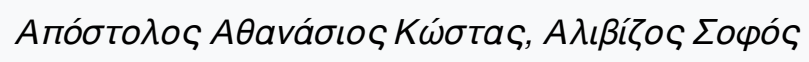

doi: $\underline{10.12681 / \text { jode. } 13877}$

The Journal for Open and Distance Education

and Educational Technology

A periodical electronic publication of the

Scientific Association: Hellenic Network

of Open and Distance Education

Bıß入ıорачıкń avaчорá: 


\title{
Peer Support during Student Teachers' Practicum: A Case Study using a Web 2.0 Community on the Cloud
}

\author{
Apostolos Kostas \\ PhD, Laboratory Teaching Staff \\ Department of Primary Education \\ University of the Aegean, Rhodes, Greece \\ apkostas@aegean.gr \\ Alivizos Sofos \\ Professor \\ Department of Primary Education \\ University of the Aegean, Rhodes, Greece \\ lsofos@aegean.gr
}

\begin{abstract}
The availability of emerging technologies in teacher's education leads to new social arrangements to coordinate the learning experience at the institutional level and the practical experience at the school level, aiming at the enhancement of teachers' preparation programs. In this context, this paper presents results from a case study taken place at the Department of Primary Education, University of the Aegean, Greece. Specifically, research focused on the impact of a cloud-based Web 2.0 online community during practicum and the perceptions that students formed as members of this community during the semester. Results highlights the role of the community as a mechanism for peer support and cooperation for student teachers during their internship in schools.
\end{abstract}

\section{Keywords}

Web 2.0; Teachers' Practicum; Cloud Computing;

\section{Introduction}

During the evolution of our civilization, technology was always a determinant factor affecting human behaviour and interaction. In this context, the evolution of Internet and World Wide Web technologies (Web 1.0, Web 2.0) has affected the educational process through various innovations. Meanwhile, technology's effects (digitization, convergence and globalization) and the consequent differentiations that bring to social sub-systems like the educational sector, have frame a new dialogue about teacher's professionalism (Sofos \& Kron, 2007), which is subject to reforms influenced by contemporary (new media in education, digital literacies, etc.) and non-contemporary issues (societal, economical, institutional) and teachers' personal, social, professional and scientific background. This dialogue is also related to the new context of meta-modernism in education, where knowledge is continuously re-negotiated and re-framed through individuals' participation in higher order formations (e.g. professional communities). In this approach, the concept of knowledge as "true" is steadily transformed to the concept of knowledge as "use", allowing an exchange of ideas among subjects and at the same 
time recognizing teachers' education as a process, organized not only top/down but bottom/up as well, within teachers' preparation academic institutions. Moreover, the last few years the international literature reveals a debate about the necessity for preparing aspiring teachers based on the new skills required $\left(21^{\text {st }}\right.$ century skills) like critical thinking, the ability to solve complex problems using technology, communication, cooperation, creativity, and innovation (AACTE, 2010), where future teachers must be able to act within learner-centred, pedagogical-sound, motivational and media-rich educational environments (Zygouyris-Coe, 2013).

Reflecting on this debate, Gomez, Sherin, Griesdorn \& Finn (2008) focusing on the relationship between technology and training of student teachers, argued that the impact of technology in teacher preparation programs have already surpassed both (a) the technology acquisition phase ( $1^{\text {st }}$ period) which was promising that technological infrastructures will automatically lead and strengthen student skills and (b) the technology integration phase $\left(2^{\text {nd }}\right.$ period) which enhanced the curriculum with various courses on digital literacies, but most of them detached from pedagogy ("Learning Design"-less). Moreover, Gomez et al. (2008) argued that the educational sector is currently going through a new phase of empowerment via technology $\left(3^{\text {rd }}\right.$ period), where the availability of emerging technologies like Web 2.0 and mobile devices (Veletsianos, 2010) could lead to new social arrangements within academic institutions, either on interinstitutional, or intra-institutional and trans-institutional level. These new technologies aim (a) to prepare media skilled future professionals based on a practice-oriented, reflective curriculum and (b) to develop teachers' networking based on virtual communities, a concept which various researchers have already urged upon since 2000 (Putnam \& Borko, 2000; Albon \& Trinidad, 2002).

Guided by these open issues and related to the preparation and training of future teachers, we conducted a case study research at the Department of Primary Education, University of the Aegean in Greece, to investigate the role of a cloud-based Web 2.0 online community as a supportive educational environment, able to facilitate student teachers during their internship in primary schools. In this article, we present results from research questions related to the evaluation of the virtual community by the users and the effect of this initiative to the overall practicum experience. Analysis and aggregation of the results showed that during the six months of internship, a "learning/developmental trajectory" was identified within the community, through which students achieved an improvement of their learning and development level, social-emotional state, and their degree of practicum satisfaction, despite any difficulties that were observed.

Following in this article, we report on a review of the literature concerning the use of ICT in support of students' practicum, next we explain the underlying research context and methodology and finally we discuss the results, aiming to "build" an interpretation on the corresponding case study research.

\section{Review of Technologies in Support of Student Teachers' Practicum}

Various research cases argue that student teachers experience anxiety during practicum and highlight this phase as the most stressful module of the curriculum, which often focus mainly on methodological issues rather on more practical aspects like new roles, responsibilities, and relationships in the schooling environment. In these cases, as summarized by Zagami (2010), researchers have characterized practicum as a demanding 
phase, because of students' perceptions about the effort and resources needed to cope with the requirements of teachers' preparation academic departments. Students during this phase have a range of concerns, from time management, educational material preparation and design of teaching plans, to academic assessment and others' expectations of their progress. Gold (1996) in his research argued that students need pedagogical \& didactic support (class management, reflection on action, students' motivation, teaching design and preparation management of "otherness" between pupils in school, etc.) and psychological support (emotional support, positive feedback, build of trust relationships, stress management, development of self-efficacy and identity, etc.). To facilitate students to overcome these difficulties during practicum, academic institutions are looking for new organizational models and pedagogical methods to enrich the undergraduate curriculums of teachers' preparation programs, aiming in supporting and strengthening the reflective thinking, self-perception, and self-efficacy of trainee teachers. This effort is related with the overall context of new media integration within the curriculum to emphasize the relation between academic learning and professional practice and connect student teachers, academic staff and schooling staff in new dynamic ways mediated by new technologies (Putnam \& Borko, 2000; Albon \& Trinidad, 2002; Gardner \& Williamson, 2002; Gomez et al., 2008). In this context, researchers have tried to investigate various aspects on the impact of ICT-mediated communities as a facilitating and supportive environment for student teachers during practicum. Hwang \& Vrongistinos (2011) used a combination of Blackboard LMS and Skype VoIP as an environment that reduced the time required for mentoring, where Skype offered additional support to participants. Overall, the evaluation was positive even though some of the advantages of F2F meetings were reduced. McLoughlin \& Lee (2007) used Blackboard LMS and Rideout, Briunsma, Hull, \& Modayil (2007) used Moodle LMS to facilitate a community of student teachers and to support e-mentoring activities. Results showed that students exchange ideas, experiences and established a peer support mechanism within the community. Figg \& Rutherford (2010) and Chu, Chan, \& Tiwari (2012) in their surveys highlighted the usefulness of Drupal CMS during practicum, based on blog's educational affordance with emphasis on the process of professional learning and peer support. Pratt (2009) who utilized Webex Video Conference System, argued that his research revealed an overall positive impact on students during their internship. Moreover Pratt (2009) stated that each technology implementation should consider the social, cultural, and historical practices already embedded in the application context and that the potential success may be influenced by the per se technology and the readiness of the subjects to accept this technology implementation. English \& DuncanHowell, $(2008,2011)$ used Facebook to organize a community among students and the research revealed the existence of social capital among students' online interactions, while cultural capital was built and objectified as well. This process was enhanced by the digital skills that users already possessed, due to the high degree of usage of social networks and mobile technology in their daily life. Boyd \& Ellison (2008) also have suggested the use of commercial social networks (Facebook, My Space) for the creation of sustainable social ties, while Munoz \& Towner (2009) argued that provision of social networking opportunities for students may enrich the learning process and the cooperation between student-teacher and student-student. Davie \& Berlach (2010) argued in their research that Wikis can support communication with students and keep track of 
their progress during practicum. Zagami (2010) and Wright (2010) used Twitter microblogging as a mean to establish a social fabric among students for sharing activities, events, achievements, and resources and reduce possible feelings of isolation among students. Reich, Levinson, \& Johnston (2011) used Ning platform as a social network during practicum and it proved a fertile environment for students to develop pedagogical issues, while they appreciated the potentiality of these environments to help them during their preparation phase as teachers and argued that they would like to make use of such networks later as professionals. Finally, forum-based communities were established within various research frameworks, where results showed that dialogues emphasized more on academic, organizational, pedagogical issues and less on peer support and development of a social fabric among students (DeWert, Babinski \& Jones, 2003; Nicholson \& Bond, 2003; Irwin \& Hramiak, 2010; Paulus \& Scherff, 2008; Wu \& Lee, 2004).

In general, review of the literature showed that there is an increased interest on the topic after 2008 and that ICT and teacher students' preparation, as a research area, lies between the Emergence and Diversification stage according to Rekkedal's model, meaning that more researchers have begun to work in the area which is maturing, different schools of thought emerge and align with more established areas in the field of educational technology (Conole, Ingraham \& Cook, 2003). Moreover, researchers used a wide range of technologies in their research settings with more emphasis on asynchronous CMC communication (from email and discussion forums to blogs and wikis) and less on synchronous communication tools like Skype and teleconference. In all the above studies, central role has the notion of "community", a social formation which by nature can facilitate the exchange of information and best practices, collaborative problem solving, development of personal identity and the strengthening of reflective practice for students (Yang, 2009). Knowledge in the community as expressed through the interaction between individuals, groups, and tools, supports the teachers' professional development (Putnam \& Borko, 2000). This fact is also supported by the research of English \& Howell (2011) which showed that social educational networks have more participation with respect to typical discussion forums within LMS, because social networks utilize more efficiently the existing social, cultural and technological capital of each community member. As Reich et al. (2011) summarized, social networks with educators as members (either inservice or trainees) and subject to educational practice (Networked Communities of Praxis) have gained ground because members expand their professional network, have access to educational resources and share experiences, teaching practices, etc. Membership in virtual educational communities reveals various advantages with respect to the support of emerging teachers (Paulus \& Scherff, 2008), if it is formatted around a focal point, i.e. the discussion and cooperation is "anchored" (Hough, Smithey, \& Everston, 2004). On the other hand, participation in a virtual community is subject to privacy, personal data security and configuration issues, if the community is mediated by non-academic, commercial, and/or public web social platforms (like Facebook, Blogger, etc.) (Figg \& Rutherford, 2010). Because CMC communication does not provide visual or intonation cues, participation does not necessarily establish trust or a sense of community among members (Paulus \& Scherff, 2008) and thus the underlying technologies must be able to support artefacts creation, collaboration, awareness, and a friendly user interface (Kostas \& Sofos, 2012). Also, the potential positive results of 
these research studies were subject to various conditional factors, such as the need of a sound instructional design in order to achieve reflective practice (Whipp, 2003), the type of messages, i.e. positive vs. negative ones (Ebenezer, 2003), the need for a clear goal for the community, a better framing of the communication with emphasis on the CMC environment (Hough, Smithey, \& Everston,, 2004), teacher's presence (Yang, 2009), individual's skills (Hramiak, Boulton \& Irwin, 2009) and lack of participants' time (Andersen \& Matkins, 2011).

Summary of the literature review's outcomes leads to some basic requirements needed for the sustainable pedagogical and technological settings of a CMC platform, as a supportive environment for student teacher's apprenticeship:

- Members of a supportive community must have access to a set of various tools (asynchronous and synchronous) within the same infrastructure.

- Community must be organized as an inter-institutional, educational, and limitedaccess network.

- Community's infrastructure must be characterized by scalability and cost efficiency for the academic institutions.

- Participation in the community must be part of an integrated approach for the practicum's design.

Coping with the above requirements, since 2010 various open source social networking engines, organized over cloud-based infrastructures have been utilized to mediate communities of educators, students, and stakeholders in respect to various disciplines.

\section{Cloud Computing}

Cloud Computing is a relative new computation paradigm. According to the official NIST (National Institute of Standards and Technology, US Dept. of Commerce) definition, "cloud computing is a model for enabling ubiquitous, convenient, on-demand network access to a shared pool of configurable computing resources (e.g., networks, servers, storage, applications, and services) that can be rapidly provisioned and released with minimal management effort or service provider interaction" (Bora \& Ahmed, 2013). It is based on technologies that enable use of computing power, storage space, software applications and services over the Internet, according to user's needs (on-demand) (Plummer, Bittman, Austin, Cearley, \& Smith, 2008). The "cloud" belongs either to an organization that offers services to its members (internal cloud), or to an organization that offers services to external users-customers (external cloud). The main classification of cloud's services is called SOA (Services Oriented Architecture) (Papazoglou \& Van Den Heuvel, 2007; Fernández, Peralta, Herrera, \& Benítez, 2012; Bora \& Ahmed, 2013) and it is based on three abstraction layers to the end user:

- SaaS (Software as a Service), where software is offered as a service over Internet, rather than as a software package to be purchased (for example, Google Docs, Gmail, Ning, Grou.ps, etc.).

- PaaS (Platform as a Service), which provides the necessary facilities to support the entire application development lifecycle of rich Web applications (for example, Microsoft Azure, etc.).

- Iaas (Infrastructure as a Service), where hardware resources and computing power are offered as services to end users, a model that enables businesses to rent 
these resources rather than spending money to buy dedicated servers and networking equipment (for example, Amazon Web Services, etc.).

On demand services over the Internet, particularly within the SaaS model, can cope with the needs of the end user on a flexible and adaptive way by charging only the actual use of the service, rather than the cost of any underlying IT infrastructure. This alternative approach may have a relatively better "performance to cost" ratio, compared with traditional IT organizational structures and especially within academic institutions, which are facing a reduction of their budgets increasingly during the last years, at national and international level. According to the literature (Fernández, Peralta, Herrera, \& Benítez, 2012; Madan, Pant, Kumar, \& Arora, 2012) there is a great interest in SaaS systems to provide e-learning services for the replacement of traditional client/server-based Learning Management Systems. Main reason for this is that due to (a) the rapid growth of users and volume of educational content and (b) the need for a better integration of web 2.0 tools within the educational process, requirements in hardware/software installations and human resources have been increased over the last years and thus the economic cost for the academic institutions have been increased, as well.

In this sense, various new e-Learning platforms based on cloud technologies, open social networking engines, new Web 2.0 educational-oriented tools, etc., can all be considered as Educational Software as a Service (ESaaS) (Fernandez et al., 2012).

\section{Research Methodology}

Following the evidence of educational affordances of Web 2.0 tools (McLoughlin \& Lee, 2007), a non-formal learning and collaborative space among educators and students during internship was set up in the Department of Primary Education, University of the Aegean, in Greece. The role of the electronic Community of Teachers Practicum (eCTP) (Kostas, Sofos \& Tsolakidis, 2013) was that of a collaborative space aiming to support and facilitate student teachers during practicum, by establishing a network of communicating peers. eCTP was designed to operate as an Internet-mediated Community of Practice (IMCoP), considering various design factors (Kostas \& Sofos, 2012). Community was mediated by the cloud-based open social networking engine Grou.ps. This SaaS service was aligned with the basic technological requirements needed for a sustainable supportive community (as explained in previous section), because:

- It reinforced the educational environment through a set of communication and collaboration tools.

- Its underlying technological infrastructure provided a working framework of privacy and trust among students, thus allowing for a limited-access interdepartmental social fabric.

- It provided more scalable and cost efficient solutions, relatively to university's existing IT infrastructures.

The requirement of an "intergated approach" concept in this research refers to the design of a sound pedagogical and technological framework integrated into the practicum process. Research settings for the pedagogical domain focused on student teachers' reflection on action (Schön, 1983) and "emerging" professional identity in a social context like communities of practice (Wenger, 1998).

An inquiry and reflective approach for the incorporation of new media in the educational process formulated a theoretical model around three dipoles (didactic transformation - 
reflection, mentoring - consulting, community - coupling), which served as the basis for the practicum within the lesson entitled "Design and Creation of Digital Content for Online Distance Learning". Practicum was spanned over sixteen (16) primary schools, covering a period of thirteen (13) weeks and organized around three (3) main phases:

- Classroom Observation (weeks: 2-4).

- Micro-Teachings (weeks: 5-7).

- Classroom Teachings (weeks: 9-11).

During these phases, students were committed to follow a specific learning design plan consisting of various open and closed learning activities like classroom observation rubrics, critical incidents journal, surveys, micro-teachings, peer evaluation of microteaching videos, weekly blogging, argumentation in community's dialogues, sharing of recourses, lesson plans design, classroom teaching, etc. Based on the literature review and the above framework, an exploratory single-case research study (Yin, 2003) was set up and "case" was defined as the "support and facilitation of the practicum via eCTP". Aim of this study was to investigate and evaluate the role of eCTP, questioning, among others, about "what the overall community's evaluation from the students was" and "how the community and the underlying pedagogical framework did affected practicum". A cohort of 165 student teachers $(M: 28, F: 137)$ actively participated in the community during the fall semester of the $4^{\text {th }}$ academic year, together with 2 moderators (professor and researcher) and 5 facilitators (ex. students). Data collection procedure followed a mixed-methods approach to achieve complementarity among quantitative and qualitative data for better reliability and substantiation (Creswell, 2008). It was based on data collected through students' electronic posts and community's final evaluation survey. Upon completion of the practicum, all entries (containing student's name and a time stamp) were copied from Grou.ps and uploaded as text files into Atlas.ti 6.2, a CAQDAS software that facilitated the qualitative data analysis. Survey consisted of 5-point Likerttype closed-ended questions and open-ended questions. It was implemented using Google Forms and was anonymously filled out by $46 \%$ of the cohort (76/165). IBM SPSS Statistics v.21 software was used to analyze data from closed-ended questions, while Atlas.ti 6.2 was used to analyze the open-ended questions.

\section{Data Analysis}

\section{Activity in the Community}

Activity in the community reflected on students' artefacts (Table 1), where according to Vygotsky (1978) an artefact is anything that can mediate human activity.

\begin{tabular}{lc}
\hline Students & $165(\mathrm{M}=28, \mathrm{~F}=137)$ \\
Moderators & 2 \\
Facilitators & 5 \\
\hline Forum posts & $1700+$ \\
Blog posts & $700+$ \\
Chat Messaging & $700+$ \\
Private Messaging & 48 \\
File sharing & $180+$ \\
Link sharing & $190+$ \\
Video sharing & $380+$ \\
Photo sharing & $480+$ \\
\hline
\end{tabular}

Table 1 - Students' artefacts in the community 


\begin{tabular}{llllll}
\hline Forum posts & & Blog posts & & Chat messages & \\
\hline Total & $1200+$ & Total & $700+$ & Total & $700+$ \\
Max posts per user & 12 & Max posts per user & 16 & Max posts per user & 69 \\
Mean posts per user & 7,8 & Mean posts per user & 4,2 & Mean posts per user & 4,6 \\
Mean post per user/week & 0,72 & Mean post per user/week & 0,34 & Mean post per user/week & 0,36 \\
\hline
\end{tabular}

Table 2 - Overall activity in the community

Members' participation facts are presented in Table 2. Members of the community produced more than 4.500 artefacts, with mean per week $=350,6$ and mean per user $=$ 27,6 a fact which is related to the survey's question "Do you consider yourself active member of the community?", where 73 students $(96,1 \%)$ answered positive and 3 students $(3,9 \%)$ answered negative.

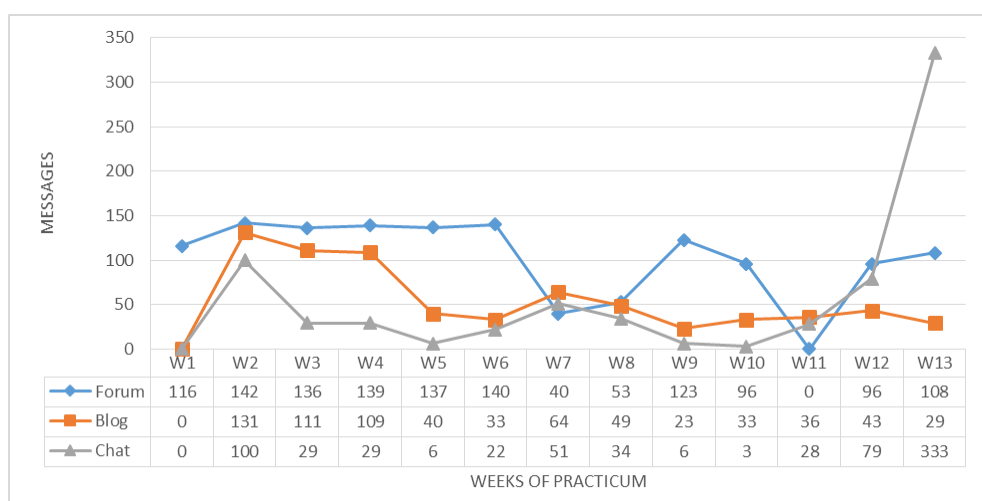

Figure 1 - Frequencies of CMC communication in the community

In Figure 1, the CMC's frequencies in the community are presented, showing the communication pattern of asynchronous and synchronous communication among students, spanned over the 13 weeks of the practicum. Concerning the technological capital of the community members, analysis found a positive correlation statistically important $(\mathrm{r}=0.223, \mathrm{p}<0.05)$ between students' mean examination marks in ICT courses and the number of artefacts, using Pearson's $r$ test between continuous and ordinal variables (Muijs, 2011, p.124).

Evaluation of the Community

By comparing "classical" practicum in the department and eCTP, $40(52,6 \%)$ students found it interesting, 37 (48,7\%) useful, 36 (47,4\%) demanding, 29 (38,2\%) effective and $15(19,7 \%)$ time consuming, while overall students' perception about the community is outlined in Table 3.

\begin{tabular}{lrrr}
\hline [Q2] Do you believe that students: & N & Mean & Std. Deviation \\
\hline Supported each other & 76 & 3,80 & 1,020 \\
Shared information & 76 & 3,86 &, 875 \\
Collaborate & 76 & 3,89 & 1,014 \\
Actively engaged in the community & 76 & 3,91 &, 769 \\
Developed a common perception about school and practicum & 76 & 4,18 &, 647 \\
Developed a sense of community belonging & 76 & 4,30 &, 693 \\
Valid N (listwise) & 76 & & \\
\hline
\end{tabular}
Notes: Ratings are based on a 5-point Likert-type scale: 1 - "Not at all" and 5 - "Highly".

Table 3 - Members perception about the community 
Using descriptive coding techniques (Saldana, 2009), we analyzed the answers of the survey question "Describe in your opinion, the 3 most important positive and negative aspects of the community", which revealed a set of categories and subcategories (Table 3, 4).

\begin{tabular}{lcc}
\hline Positive Aspects of the Community & Frequency & $\%$ \\
\hline Interaction: peer collaboration (22), exchange of ideas/experiences (19), sharing (6), & 55 & 71,42 \\
dialogue (4), personal expression (4) & & \\
Update: news (20), info (10), course obligations (11), practicum (5), announcements (4) & 50 & 64,93 \\
Communication & 27 & 35,06 \\
Personal development: ICT skills (7), teaching skills (7), new knowledge (4) & 18 & 23,37 \\
Support: problem solving (16), peer support (8) & 24 & 22,94 \\
Course: practicum design (9), organization (7) & 16 & 20,77 \\
Platform: usability (8), content organization (5) & 13 & 16,88 \\
Socialization & 12 & 16,00 \\
Individual's work (better schedule) & 11 & 14,28 \\
\hline
\end{tabular}

Table 4 - Positive Aspects of the Community

\begin{tabular}{lcc}
\hline Negative Aspects of the Community & Frequency & $\%$ \\
\hline Individual's work: time consuming (19), work load (13), stress (9) & 41 & 53,24 \\
Process: demanding (24), organizational difficulties (11) & 35 & 45,45 \\
Platform: file system (12), connectivity (9), various technical problems (6) & 27 & 35,06 \\
Way of working & 7 & 09,09 \\
None & 5 & 06,49 \\
\hline
\end{tabular}

Table 5 - Negative Aspects of the Community

Concerning the various benefits that students gained through their participation in the community, results from the Question 11 of the survey are presented in Table 6.

\begin{tabular}{|c|c|c|c|}
\hline $\begin{array}{l}\text { [Q11] In which degree, each of the following statements } \\
\text { corresponds to benefits you obtained through the community? }\end{array}$ & $\mathrm{N}$ & Mean & Std. Deviation \\
\hline I found psychological support & 76 & 3,25 & 1,179 \\
\hline I was helped to solve my problems & 76 & 3,78 & 1,053 \\
\hline I found useful information to improve my lesson plans & 76 & 3,83 & 1,100 \\
\hline I exchange ideas and experiences with my classmates & 76 & 3,95 & 1,070 \\
\hline I better organized my work during the semester & 76 & 4,00 & ,966 \\
\hline I improved my teaching techniques & 76 & 4,04 & 1,051 \\
\hline I was better informed and prepared for my classroom teaching & 76 & 4,14 & 890 \\
\hline I better communicated with my classmates and teachers & 76 & 4,14 & ,812 \\
\hline I better understood course subject & 76 & 4,16 & 1,007 \\
\hline I was better informed about classroom observation phase & 76 & 4,32 & 836 \\
\hline I clarified questions about micro-teachings & 76 & 4,37 & ,763 \\
\hline Valid N (listwise) & 76 & & \\
\hline
\end{tabular}
Notes: Ratings are based on a 5-point Likert-type scale: 1 - "Not at all" and 5 - "Highly".

Table 6 - Members statements about community's benefits

Moreover, data related to community's evaluation derived from a source outside the original research plan, namely the posts of forum's weekly topic "Document an important educational circumstance of your classroom teaching". In this thread, in a total of 96 posts, 66 had a direct reference to the community and descriptive analysis of the posts identified various key elements of eCTP, like strengthening of communication and information on various topics of the practicum, support and assistance provided to the 
students and innovation in process, even though workload and stress were addressed as two negative characteristics.

The following excerpts are some representative examples of these posts:

Community helped us to communicate, to exchange thoughts and anxieties about the profession, our attitudes toward things and our expectations about classroom teaching. Also, it helped us to stay informed about the weekly work schedule.

This community would solve in the future many questions and problems and would guide us on what exactly we should be doing every week.

This design was an original and unusual experience for us. We were given the opportunity to exchange thoughts, record our experiences and talk about issues preoccupying us during practicum.

I can say that community helped me, even though process was time consuming and demanding.

Finally, using an adopted version of the Inventory of Experiences and Perceptions at Teaching Practice (Caires \& Almeida, 2005) we conducted a Paired Samples t-Test for the mean values between start and end of the semester (pre-post test) and sub-scales shows positive variation through the semester, where high values correspond to higher levels of students' positive perceptions about practicum (Table 7). Comparing to Caires \& Almeida (2005) research, where practicum was not mediated by ICT, in our case there was a significant variation in the sub-scales SEA and SRS, as an indicator of increased satisfaction of students in relation to the level of support they had during practicum, assistance and guidance received from the university and the school, which affected positively their psychology and self-esteem and enhanced their perception about practicum experience.

\begin{tabular}{|c|c|c|c|c|c|c|c|}
\hline \multirow[t]{2}{*}{ Sub-scales } & \multicolumn{2}{|c|}{ Start of semester } & \multicolumn{2}{|c|}{ End of semester } & \multicolumn{3}{|c|}{$t$-Test } \\
\hline & Mean & $\mathrm{SD}$ & Mean & $\mathrm{SD}$ & $\mathrm{T}$ & $\mathrm{df}$ & $P^{*}$ \\
\hline $\begin{array}{l}\text { Learning Professional } \\
\text { Development (LPD) }\end{array}$ & $21,75(3,11)$ & 5,62 & $23,37(3,34)$ & 2,52 & $-2,58$ & 92 & ,011 \\
\hline $\begin{array}{l}\text { Social Emotional Aspects } \\
\text { (SEA) }\end{array}$ & $36,35(2,59)$ & 11,00 & $42,33(3,02)$ & 5,60 & $-4,94$ & 92 & ,000 \\
\hline $\begin{array}{l}\text { Support Resources } \\
\text { Supervision (SRS) }\end{array}$ & $24,84(2,76)$ & 9,35 & $29,67(3,30)$ & 4,44 & $-4,51$ & 92 & ,000 \\
\hline
\end{tabular}

Table 7 - IEPTP Paired Samples t-Test

\section{Community's influence on the practicum}

Answers to the Question 12 of the survey "How did community affected the way that you organized your practicum, with respect to the phases of classroom observation, microteachings and classroom teaching?" reflected the overall students' perception, as the following excerpts highlights:

I could share questions, experiences, and ideas with my fellow students at any time. Also, sharing files of the practicum helped me organize and group all actions needed. Moreover, community helped me find and meet my colleagues for the school placement with whom I had to work. Moreover, all notes, video, and files that were uploaded, I believe that they were very helpful for us!

In each of the phases of the practicum, community with the instructions and information provided, has helped me understand the needs and objectives of the course. In each phase, I could find answers to questions, either through my classmates, or through the instructor and his 
associates and thus I able to cope to the different course's requirements during each phase of the practicum.

Using Open/Initial Coding (Saldana, 2009), we identified various themes within the data which shows a differentiation of community's influence per practicum's phase. Table 8 below presents the six most significant themes.

[Q12] How did community affected the way that you organized your practicum, with respect to the phases of classroom observation, micro-teachings and classroom teaching?

\begin{tabular}{lcccccr}
\hline & Class Observation & $\%$ & micro-Teaching & $\%$ & Class Teaching & \multicolumn{1}{c}{$\%$} \\
\hline Personal diary & $\mathbf{1 6}$ & $\mathbf{2 1 , 0 5}$ & 2 & 2,63 & 2 & 2,63 \\
Information/updates & $\mathbf{1 3}$ & $\mathbf{1 7 , 1 1}$ & 11 & 14,47 & 8 & 10,53 \\
Problem solving & $\mathbf{1 1}$ & $\mathbf{1 4 , 4 7}$ & $\mathbf{2 3}$ & $\mathbf{3 0 , 2 6}$ & $\mathbf{2 0}$ & $\mathbf{2 6 , 3 2}$ \\
Communication & 8 & 10,53 & 2 & 2,63 & 7 & 9,21 \\
Sharing & 8 & 10,53 & $\mathbf{2 0}$ & $\mathbf{2 6 , 3 2}$ & $\mathbf{1 5}$ & $\mathbf{1 9 , 7 4}$ \\
Work organization & 8 & 10,53 & $\mathbf{1 3}$ & $\mathbf{1 7 , 1 1}$ & $\mathbf{1 2}$ & $\mathbf{1 5 , 7 9}$ \\
\hline
\end{tabular}

Table 8 - Community vs. practicum phases

During classroom observation (weeks: 2-4) students focused on the use of the blog to record their personal experiences and impressions about school and to "listen" to their colleagues. In this way, they could compare their own with others' experiences and evaluate the situation more globally and be familiarized with school environment and students' need, via observation rubrics and analysis tools.

Tools of eCTP were useful as we could reflect on our experiences via blogging.

Through eCTP I had the opportunity to be informed about the school in which I would carry out my practicum, to record my experiences from this school and to be informed and compare mines with observations of my classmates.

We could, through the diary, to share our impression with our classmates and read their own.

It helped me understand the climate of the class, level of students, the conditions of the class, to design my teaching.

During micro-teaching (weeks: 5-7) students focused on problem solving and questions concerning the process of micro-teaching preparation. With video sharing of microteaching examples, they had the opportunity to better understand this pedagogical approach and prepare their own. Also, by uploading their micro-teachings' video, they had the opportunity to be involved in a peer-review process.

I had the opportunity to watch the videos presented, to comment one of them and get ideas for organizing my own micro-teaching.

I was helpful to watch other's micro-teachings and improve my own!

Information and guidance for the creation of our micro-teaching and consolidation of the process.

It contributed to my best preparation for teaching, as the community helped me to understand what is micro-teaching and what exactly I had to do.

Finally, during classroom teaching (weeks: 9-11) students focused on questions concerning lesson plans about classroom teaching preparation and course deliverables and assessment.

Community helped me in my teaching design because once again I was getting information and studying uploaded files from my teacher and classmates.

I found resources for my teaching and through the blog I understood similar problems of my colleagues and so I could find the right solution. 
The lesson drafts, the weekly forum themes, chatting with my fellow students, teacher's advices and assistant and file sharing, helped me design my lesson plan.

It helped me understand how a structured teaching is, how should learning objectives be set and evaluated and how we could manage time. After the presentation, I spotted some mistakes which I tried not to repeat in classroom teaching.

\section{Discussion}

Based on the community life-cycle model of Cambridge \& Suter (2005), eCTP followed all the intermediate development phases needed for a successful operational pattern (in respect to activity and members' relationships) which was characterized by a normal operational identity, a clear organizational and administrative model, distinct (anchored) learning goals and homogeneity among members. This operational pattern enhanced the social capital of students, as it was reflected on their perceptions about their participation in the community, leading to the emergence of interaction between students, which was strengthened by their experience in using various social networks, as English \& Howell (2011) have documented. Also, students' digital capital (i.e. degree of students' familiarity with ICT in education based on various courses) helped the development of the social capital in the community, because activity as a quantitative magnitude (number of artefacts) had a statistically significant correlation with the average mean scores on those courses. Moreover, high level of familiarity with the platform, as the students documented it, was consistent with Prat (2009) research according to which technological interventions in teachers' preparation programs are directly influenced by the degree of subjects' preparedness to adopt to these interventions. As a consequent of interaction, communication emerged as one of the main benefits of the community, especially at the level of synchronous communication, as was demonstrated by the degree of chat utilization (Kostas et al., 2015). The dimension of communication between students through their participation in online environments, was also highlighted by Davie \& Berlach (2010) and Wright (2010).

Moreover, information (updating) emerged as a significant dimension, especially on issues related to the organization of the course and the practicum: continuous, updated and reliable information, in the broader context of the academic community, is an enduring need and requirement of its members, which appeared to be fulfilled by the community, even within the narrow "space-time frame" of a six-month course. Indeed, information updating, especially in classroom observation and teaching, was a major concern of our students and was documented as one of the key benefits of the community, as other studies have documented (Nicholson \& Bond, 2003; McLoughlin et al., 2007; Zagami, 2010). At the same time, benefits of participation such as better organization of personal work, multi-layered support, better understanding of the course and better preparation of teaching through improvements on pedagogical practices, was documented by the students. This revealed the dimension support during students' internship, as a key outcome of this research, which came to confirm previous studies (Hung, 2008; Fing \& Rutherford, 2010). Support also reinforced the dimension of personal development of students, bounded as the acquisition of new knowledge, improvement of existing knowledge and development of professional and personal skills, an outcome which was partly converge towards the dimension of professional development of the trainee teachers. Comparing the experiences of students in relation to other models of practicum design, the students stated an overall positive perception of the 
pedagogical and technological framework, with the proposition for further use of this model in the curriculum. Students highlighted the usefulness and effectiveness of this supporting structure and the diversity and originality in relation to what they had met in other practicum settings. An interesting outcome was the variations of community's effectiveness per phase, as each member prioritized it. For example, during classroom observation phase, emphasis placed on the role of the community as a mean of stamping personal experience of students in school. However, through peer sharing in the community, this experience ceases to be an individual and becomes a collective one, since it allowed the members to "listen" their colleagues, giving them the opportunity for a comprehensive understanding of "school reality", i.e. school environment and pupils" needs.

Based on the analysis of all research results, this study highlighted the existence of a developmental/learning trajectory (Figure 2) through which student teachers achieved improvement in their level of learning and professional development, their socioemotional status, and their degree of satisfaction about the practicum, while strengthening their perceptions about technology and teaching practice. On the other hand, this trajectory while it was leading students towards self-improvement, it was creating more workload and lesson requirements, which in some cases created fatigue and stress among students and was stated as a negative aspect of this process.

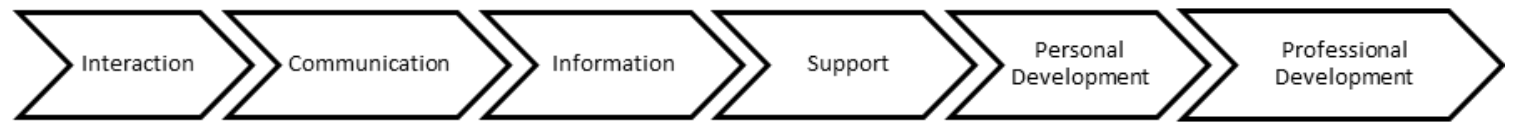

Figure 2 - Developmental/learning trajectory in the community

Concerning the technical infrastructure, some problems were reported, mainly on the organization of the file system of the platform. However, Grou.ps social networking engine as a cloud service proved a viable technological solution, comparing to in-house solutions, for the creation of virtual communities with a high degree of reliability and security and low running and maintenance costs, thus confirming other studies on Educational SaaS (Masud \& Huang, 2011; Madan et al., 2012).

\section{Conclusions}

This study through the analysis, correlation, and interpretation of qualitative and quantitative research data, confirms the initial hypothesis embedded in the literature, that participation of student teachers in electronic communities with a specified knowledge domain and practice, clearly defined learning goals (anchored) and tools for communication, sharing and interaction, lead to the development of a supportive environment. This environment, in our case acted as a facilitating agent empowering students during their internships, strengthening their reflective thinking and helping them to better understand the profession. Aggregating our conclusions, we agree with Barab, MaKinster \& Scheckler (2004) according to whom, a community of practice is a sustainable social network of individuals who share and develop an overlapping cognitive background, set of personal values, stories, and experiences, focusing on common practices, where primary objective is not learning in the community, but rather the 
community itself as a fertile environment for the development of social capital, knowledge, and innovation.

\section{References}

AACTE-American Association of Colleges of Teacher Education and the Partnership for $21^{\text {st }}$ Century Skills (P21) (2010). $21^{\text {st }}$ century knowledge and skills in educator preparation.

Albon, R., \& Trinidad, S. (2002). Building learning communities through technology. In K. Appleton, C. Macpherson \& D. Orr (Eds.), International Lifelong Learning Conference: refereed papers from the $2^{\text {nd }}$ International Lifelong Learning Conference, Yeppoon, Central Queensland, Australia, 16-19 June 2002 (pp. 50-67). Rockhampton, Old: Central Queensland University Press.

Andersen, L., \& Matkins, J. (2011). Web 2.0 Tools and the Reflections of Preservice Secondary Science Teachers. Journal of Digital Learning, 28(1), 27-38.

Barab, S., MaKinster, J., \& Scheckler, R. (2004). Designing system dualities: Characterizing an online professional development community. In S. Barab, R. Kling \& J. Gray (Eds.), Designing for virtual communities in the service of learning (pp. 53-90). Cambridge: Cambridge University Press.

Bora, U., J., \& Ahmed, M. (2013). E-learning using Cloud Computing. International Journal of Science and Modern Engineering, 1(2), 9-13.

Boyd, D., \& Ellison, N., B. (2008). Social network sites: Definition, history and scholarship. Journal of Computer-Mediated Communication, 13(1), 210-230.

Caires, S., \& Almeida, L., S. (2005). Teaching practice in Initial Teacher Education: its impact on student teachers' professional skills and development. Journal of Education for Teaching, 31(2), 111-120.

Cambridge, D., \& Suter, V. (2005). Community of practice design guide: a step-by-step guide for designing \& cultivating communities of practice in higher education. Educause CONNECT: Transforming Education Through ICT.

Creswell, J., W. (2008). Research Design: Qualitative, Quantitative, and Mixed Methods Approaches. Thousand Oaks: SAGE Publications.

Davie, S., \& Berlach, R. (2010). Using Wikis to Facilitate Communication for Rural, Remote and At-Risk Practicum Students. MERLOT Journal of Online Learning and Teaching, 6(1), 78-88.

DeWert, M. H., Babinski, L. M., \& Jones, B. D. (2003). Safe Passages: Providing Online Support to Beginning Teachers. Journal of Teacher Education, 54, 311-320.

Ebenezer, J., Lugo, F., Beirnacka, B., \& Ruvirajah, A. (2003). Community Building through Electronic Discussion Boards: Pre-Service Teachers' Reflective Dialogues on Science Teaching. Journal of Science Education and Technology, 12(4), 397-411.

English, R., \& Howell, J. (2011). Virtual Communities as Tools to Support Teaching Practicum: Putting Bourdieu on Facebook. In B. Daniel (Ed.), Handbook of Research on Methods and Techniques for Studying Virtual Communities: Paradigms and Phenomena 2 (Vols.) (pp. 233-247). Hershey, PA: Information Science Reference.

Fernández, A., Peralta, D., Herrera, F., \& Benítez, J., M., (2012). An Overview of E-Learning in Cloud Computing. In L. Uden, E. S. C. Rodríguez, J. F. De Paz Santana \& F. De la Prieta (Eds.), Workshop on Learning Technology for Education in Cloud (LTEC'12), Advances in Intelligent Systems and Computing Volume 1732012 (pp. 35-46). Berlin/Heidelberg: Springer.

Figg, C. \& Rutherford, C. (2010). Using Social Networks to Enhance Pre-service Teachers' Understanding of Professional Identity. In D. Gibson \& B. Dodge (Eds.), Proceedings of Society for Information Technology \& Teacher Education International Conference 2010 (pp. 482-489).

Gardner, C. \& Williamson, J. (2002). The practicum in the Internet Age: The use of WebCT to facilitate learning from school experience. Paper presented at the Australian Teacher Education Association, Brisbane.

Gold, Y. (1996). Beginning teacher support: Attrition, mentoring, and induction. In J. Sikula, T. J. Butterly, \& E. Guyton (Eds.), Handbook of research on teacher education (pp. 548-594). New York: Macmillan.

Conole, G., Ingraham, B., \& Cook, J. (2003). Learning technology as a community of practice. Paper presented at the British Educational Research Association Annual Conference, Heriot-Watt University, Edinburgh, 11-13 September 2003. 
Gomez, L., Sherin, M., Griesdorn, J. \& Finn, L., E. (2008). Creating social relationships: The role of technology in preservice teacher preparation. Journal of Teacher Education, 59(2), 117-131.

Hramiak, A., Boulton, H. \& Irwin, B. (2009). Trainee teachers' use of blogs as private reflections for professional development. Learning, Media and Technology, 34(3), 259-269.

Hough, B., Smithey, M. \& Everston, C. (2004). Using CMC to Create Virtual Communities of practice for Intern Teachers. Journal of Technology and Teacher Education, 12(3), 361-386.

Hung, H. (2008). Teacher learning: Reflective practice as a site of engagement for professional identity construction. US-China Education Review, 5(5), 39-49.

Kostas, A., Sofos A., Tsolakidis K., \& Bratsalis K. (2011). Educational Web Communities in Greece: A Critical Survey. In K. Fernstrom \& K. Tsolakidis (Eds.), Education and Technology: Innovation and Research, Proceedings of ICICTE 2011 (pp. 103-111). Fraser Valley, Canada: University of the Fraser Valley Press.

Kostas, A., \& Sofos, A. (2012). Internet-Mediated Communities of Practice: Identifying a Typology of Critical Elements. In T. Daradoumis, S. Demetriadis, \& F. Xhafa (Eds.), Intelligent Adaptation and Personalization Techniques in Computer-Supported Collaborative Learning, Studies in Computational Intelligence, 2012, Volume 408/2012, (pp. 311-334). Berlin/Heidelberg: Springer.

Kostas, A., Sofos, A., \& Tsolakidis, C. (2013). Facilitating student teachers during practicum: A case study using a web 2.0 online community. In L. Morris, \& C. Tsolakidis, C. (Eds.), Proceedings: International Conference on Information Communication Technologies in Education (ICICTE) 2013 (pp. 343-353), Chania, Greece.

Kostas, A., Sofos, A, \& Tsolakidis, C. (2015). The role of instant messaging during practicum: Lessons learned from a case study. In L. Morris \& C. Tsolakidis (Eds.), ICICTE (International Conference on Information Communication Technologies in Education) 2015 Proceedings (pp. 257-263).

Leo, B. (1990). Teacher development through reflective teaching. In J. C. Richards \& D. Numan (Eds.), Second language teacher education (pp. 2002-2014). New York: Cambridge University Press.

Madan, D., Pant, A., Kumar, S., \& Arora, A. (2012). E-learning based on Cloud Computing. International Journal of Advanced Research in Computer Science and Software Engineering, 2(2).

Masud, A., H. \& Huang, X. (2011). ESaaS: A New Education Software Model in E-Learning Systems. In M. Zhu (Ed.), ICCIC 2011, part V. CCIS, vol. 235 (pp. 468-475). Heidelberg: Springer.

McLoughlin, C., \& Lee, M. J. (2007). Social software and participatory learning: Pedagogical choices with technology affordances in the Web 2.0 era. In ICT: Providing choices for learners and learning. Proceedings ascilite Singapore 2007 (pp. 664-675).

Muijs, D. (2011). Doing Quantitative Research in Education with SPSS (Second Edition). NY: SAGE Publications.

Munoz, C., \& Towner, T. (2009). Opening Facebook: How to Use Facebook in the College Classroom. In I. Gibson (Ed.), Proceedings of Society for Information Technology and Teacher Education International Conference 2009 (pp. 2623-2627). Chesapeake, VA: AACE.

Papazoglou, M., \& Van Den Heuvel, W.J. (2007). Service oriented architectures: Approaches, technologies, and research issues. VLDB Journal, 16(3), 389-415.

Paulus, T., \& Scherff, L. (2008). Can anyone offer any words of Encouragement? Online Dialogue as a Support Mechanism for Preservice Teachers. Journal of Technology and Teacher Education, 16(1), 113-136.

Plummer, D., Bittman, T., Austin, T., Cearley, D., \& Smith, D., (2008). Cloud Computing: Defining and Describing an Emerging Phenomenon. Gartner.

Pratt, N. (2009). Using Multipoint Audio-Conferencing with Teaching Students: Balancing Technological Potential with Practical Challenges. In R. Donnelly, \& F. McSweeney (Eds.), Applied E-Learning and E-Teaching in Higher Education (pp. 290-309). Hershey, PA: Information Science Reference.

Putnam, R., T., \& Borko, H. (2000). What do new views of knowledge and thinking have to say about research on teacher learning? Educational Research, 29(1), 4-15.

Reich, J., Levinson, M., \& Johnston, W. (2011). Using Online Social Networks to Foster Preservice Teachers' Membership in a Networked Community of Praxis. Contemporary Issues in Technology and Teacher Education, 11(4), 382-397.

Rideout, G., Briunsma, R., Hull, J., Modayil, J. (2007). Online learning management systems (LMS) and sense of community: A pre-service practicum perspective. Canadian Journal of learning and Technology, 33(3).

Saldana, J. (2009). The Coding manual for Qualitative Researchers. London: SAGE. 
Schön, D., A. (1983). The reflective practitioner. How professionals think in action. London: Tample Smith.

Veletsianos, G. (2010). Emerging Technologies in Distance Education. Edmonton, CA: AU PRESS.

Vygotsky, L. S. (1978). Mind in Society. Cambridge: University Press.

Wenger, E. (1998). Communities of practice: learning, meaning, and identity. New York: Cambridge University.

Whipp, J., L. (2003). Scaffolding Critical reflection in Online Discussions: Helping Prospective teachers Think Deeply about Field Experiences in Urban Schools. Journal of Teacher Education, 54(4), 321333.

Wright, N. (2010). Twittering in teacher education reflecting: on practicum experiences. Open Learning: The Journal of Open, Distance and e-Learning, 25(3), 259-265.

Wu, Cheng-Chih, \& Lee, G., C. (2004). Use of CMC in a teaching practicum course. International Journal of Science and Mathematics Education, 2, 511-528.

Yang, S-H. (2009). Using Blogs to Enhance Critical Reflection and Community of Practice. Educational Technology \& Society, 12(2), 11-21.

Yin, R., K. (1984). Case Study Research Design and Methods. Beverly Hills, CA: Sage.

Zagami, J. (2010). Twittering to Survive Practicum. ACEC2010: DIGITAL DIVERSITY CONFERENCE, 6-9 April, Melbourne, Australia. 